\title{
Problems of competitiveness as limiting factors in the development of medical tourism in Russia
}

\author{
Eugenia Vasyuta, ${ }^{1, *}$ \\ ${ }^{1}$ Russian Presidential Academy of National Economy and Public Administration, 344002, 70/54 \\ Pushkinskaya str., Rostov-on-Don, Russia
}

\begin{abstract}
Since ancient times, health remains one of the most critical values that draws close attention at the modern stage of development. Based on the Concept of Long-term Socio-economic Development of the Russian Federation until 2020, the formation of values associated with the development and maintenance of a healthy lifestyle is one of the priorities of state policy. The individual's fast-paced lifestyle is driven by the fact that the travels that mainly pursue health and recreation goals are highly significant, including in the territory of the Russian Federation. This article provides an assessment of health and recreation potential of tourism in the Russian Federation, identifies main issues of its competitiveness and its economic value. The paper speaks in favour of government interference into the tourism industry activity by means of different regulation methods in order to stimulate more efficient activity and development.
\end{abstract}

Since ancient times, health remains one of the most critical values that draws close attention at the modern stage of development. The individual's fast-paced lifestyle is driven by the fact that the travels that mainly pursue health and recreation goals are highly significant, including in the territory of the Russian Federation.

Russia is a huge country with a great economic potential, and for its economy to function effectively, it needs centralized management of all sectors of the economy and, in particular, the social sphere, which includes tourism.

As the development of the world and Russian economy of recent years has shown, the issues of improvement and development of public administration in the economic complex of the country remain relevant. A strong economy needs state support.

Presently, tourism is one of the developing sectors of global economy. Tourist activity becomes one of state income items and, accordingly, ranks high among the most prospective industries of national economies. Over 300 million people are employed in the service sector that accounts for nearly one third of the global service trade [2].

Reduction of various barriers in the international service trade resulting, in turn, from globalization processes has been indisputably driving the growth of the health and recreation services market and emergence of new forms of health tourism.

In the meantime, one of the popular tourist activities is health tourism.

* Corresponding author: eug.vasuta2012@yandex.ru 
In the context of integration of economic processes, development of health tourism makes medicine develop at the higher rate due to the increased competition. Health tourism has material social and economic effect on development of tourist and recreational territories, so evaluation of its development and formulation of offers for its implementation are important for national economy. Implementation of the best foreign practices in providing health and recreation services is likely to bring competitiveness of Russia in the global market to the next level.

Development of international trade in the medical field, migration of various medical technicians, emergence of the most advanced diagnostic and treatment techniques along with the general production standardization could be definitely viewed as trends that would in the long run lead to overhauling of the health and recreation services market and further development of health and recreation tourism.

Trade and exchange of medical services at the international level lead to the indisputable growth of competition that, in turn, results in higher quality and performance of the above services, on the one hand. On the other hand, the process such as "highly qualified employee attrition" is observed.

There can be no dispute that domestic politics of most countries drive the development of globalization processes in the field of health service provision, yet sometimes they restrain those processes.

Besides, it is in the interests of the state that the medical service provision system would be improved through retention of qualified personnel and support for the balanced coexistence of private and public medicine.

In fact, the strategy of tourism development in the Russian Federation by 2020 states that current tourism must be both a kind of the regional development locomotive and a link between business interests of diverse marketplaces, priorities of state politics and cultural needs of the society [1].

Unity of objectives and tasks of national development would allow implementation of result-oriented instruments to grow the cultural level, intellectual potential and wealth of the country and each of its citizens.

Therefore, state regulation of the field of health and recreation tourism is one of the fundamental factors of industry development.

This is because the lack of clear understanding of institutional aspects of actions focused on regulation of the tourism area at the federal, regional and municipal levels does not allow the tourist activity to be carried out efficiently and professionally in the domestic and global health and recreation service markets.

Unfortunately, the state of national state policy in the field of health and recreation tourism does not meet the modern global standards of industry management at the federal level which, in turn, restrains the possibility to effectively use the touristic recreational potential of national health and recreation compounds.

So, this is what a Russian tourist expects from health and recreation services provided abroad [4]:

- accurate and fair diagnosis;

- opportunity to undergo various treatment procedures, including the most complex ones;

- command the services of Russian-speaking physicians;

- opportunity to undergo treatment with the use of modern and harmless drugs;

- command the services of an escorting interpreter;

- receive assistance in organizing his or her staying abroad and other services.

- application of techniques of nonconventional and oriental medicine;

- highly professional physicians and highly trained paramedical staff;

- top-level hospital service, etc. 
Yet, in the context of sanctions a trend associated with some reduction of travels of Russian residents to international resorts for health and recreational purposes is expressly observed.

The territory of Russia provides for all necessary conditions required for effective development of "tourist treatment and recreation: in all of the most common areas [5]:

- climatic therapy suggests the use of treatment and disease prevention methodologies through proportional positive exposure to climatic and weather facts and effects of special procedures on human body;

- balneology is associated with research of properties of various mineral waters, their application and effects on human body;

- balneotherapy is a related area; it focuses on development of methodology for treatment, preventive care and body recovery with the use of mineral waters (both natural and artificial-prepared ones);

- mud therapy focuses on the use of treatment and disease prevention methodology with the use of therapeutic muds of diverse origin (peloids);

Before speaking of key prospective lines of activity associated with improvement of service quality at health and recreational facilities and supervised by the government, it would be reasonable to highlight the number of requirements that might ensure achievement of service quality in this area. The following can be attributed to the key requirements [3]:

1.Interest from top executives. Generally, improvement of quality of works and, accordingly, services provided depends on professional interest from executives of the key business units.

2. Professional buy-in from all employees of a health and recreational facility. The quality level of services provided directly depends on business units that directly interact with customers (patients) rather than on the department that manages quality of services provided. This department provides for general management of the process associated with improvement of quality of works in general, including quality of services provided;

3. Alignment of quality and projection based on customer requirements. Quality, as the customer sees it, directly depends on whether his or her specific individual requirements have been met. Unfortunately, presently most facilities of sanitarium and health resort type adhere to the traditional administrative quality system where quality is maintained based on compliance with standard parameters - for instance, with the scope of work, standards, technical specifications, etc. One should make sure that assessment of customer requirements is primary rather than secondary significance;

4. Service quality improvements from agencies (tourist agencies and tour operators) directly engaged in marketing of health and recreation services. Presently, senior executives of most providers both realize and make some efforts associated with creation of effective marketing channels that, in turn, are a sort of a link with the end consumer.

Still, the government is required to create the price control system for dealers, as any misconduct by partners would result in loss of image and customers, accordingly.

5. Implementation of the employee motivation system on a price and non-rice basis. Financial and moral stimulation of employees at health and recreational facilities is a prerequisite for consistent fulfillment of their professional duties. Given these factors, the number of initiatives associated with improvement of service quality at health and recreational facilities must be carried out. The government should also initiate support for internal marketing.

Another aspect directly associated with modernization of the state regulation system for health and recreation tourism in Russia is support for organization of health and recreation tourism from the perspective of implementation of new entities in the health and recreation 
services market. In this respect, it is referred to establishment of special health and recreation tourist centers (hereinafter referred to as health center).

In doing so, provision of health and recreation service should take place through communication between the health center, tourist company (tourist agency) and health and recreation compound (Figure 1).

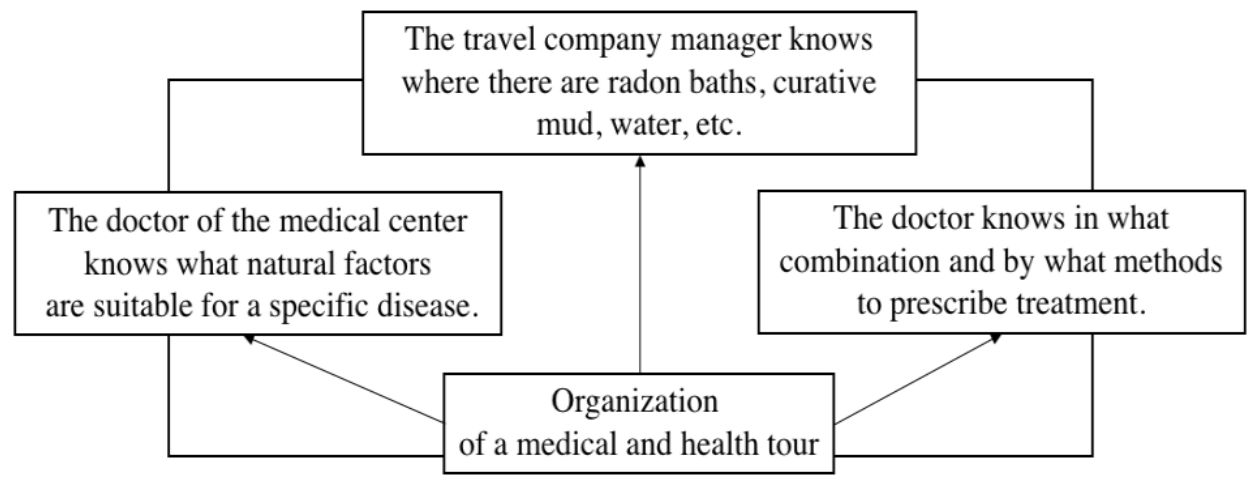

Fig. 1. "Mechanism of health and recreation tourism organization" [6]

Speaking of growth potential of national health and recreation tourism, it would reasonable to outline prospective measures of state regulation and support for health and recreation tourism in the Russian Federation:

1. Establishment of a unified interdepartmental state regulatory agency that will supervise management of the federal register of medical and recreational service providers. This circumstance is connected with the fact that the Ministry of Healthcare of the Russian Federation that currently supervises this activity has narrowed it to medical component aspects. Presently, the Federal Tourism Agency provides for only partial health tourism aspects;

2. Development of the Federal Target Program for development of the sanatorium and health resort industry. It mainly refers to the fact the Concept of state regulation of sanatorium and health resort business proposed by the Ministry of Healthcare of Russia has failed to get the interdepartmental status and has not been ratified by the Government;

3. Acknowledgement of sanatorium and health resort treatment as an insured event and its inclusion in compulsory and voluntary health insurance;

4. Promotion of using voluntary health insurance for payment of health resort aid in terms of legislation through the increased share of deductions from the payroll budget. Furthermore, changes should be introduced to the insurance base associated with payment of the health resort package in full rather than only its medical component;

5. Reduction of tax burden on health resort facilities (with regard to VAT), real estate and property tax and other various fees. Application of seasonal ratios to the size of tax rates during a calendar year;

6. Rejection from the so-called uniform health resort package and, as consequence, payment only for services actually used.

7. Medical facilities can develop patient information packets, signage and staff language and cultural training programs that focus on the needs and expectations of these targeted patient groups. It is also easier and more cost-effective to hire and train medical interpreters for those few languages. It is important to recognize that, although a bilingual staff is the best way to assure patient/caregiver communication, it is not enough for organizations to allow staff to self-evaluate their fluency in another language. 
All "bilingual" staff must be formally tested by a professional who can accurately evaluate their ability to communicate effectively with patients in that language. Also, culture will impact the interpretation of specific words because some speak the same language, but come from different cultures or even social backgrounds. While most countries do not have the stringent malpractice laws that exist in the United States, certainly a hospital's record of medical errors and the patient's satisfaction with his/her ability to communicate with both medical and non-medical staff have a strong effect on both the hospital's and the country's medical tourist growth and return on investment.

Before suggesting a strategy that would be able to improve competitiveness of national health and recreation tourism and eradicate some existing challenges, it would be reasonable to conduct SWOT analysis of health and recreation potential of tourism in the Russian Federation (Table 1).

Table 1. "Assessment of health and recreation potential of tourism in the Russian Federation".

\begin{tabular}{|c|c|}
\hline Strengths & Weaknesses \\
\hline $\begin{array}{l}\text { 1. Vast network of health resort facilities across the } \\
\text { territory of the country established on the basis of } \\
\text { favorable natural climatic and ecological conditions } \\
\text { (actual presence of seasonality); } \\
\text { 2. Availability of material and technical resources } \\
\text { in most special healthcare facilities that meet the } \\
\text { international standards; } \\
\text { 3. Highly qualified top- and mid-level medical } \\
\text { personnel; } \\
\text { 4. Acceptable cost of medical and health and } \\
\text { recreation services in the region. }\end{array}$ & $\begin{array}{l}\text { 1. Low quality level of material and } \\
\text { technical resources in sanitarium and } \\
\text { health resort facilities; } \\
\text { 2. Low servicing level in sanitarium and } \\
\text { health resort facilities in general; } \\
\text { 3. Lack of qualified medical personnel } \\
\text { in sanatorium and health resort facilities; } \\
\text { 4. Competition from health and } \\
\text { recreation and resort zones of foreign } \\
\text { countries. }\end{array}$ \\
\hline Opportunities & Threats \\
\hline $\begin{array}{l}\text { 1. Attraction of investors for implementation of } \\
\text { prospective investment projects in the area of health } \\
\text { and recreation tourism; } \\
\text { 2. Increase of the number of jobs in connection with } \\
\text { the cluster development of the area of health and } \\
\text { recreation tourism in specific regions; } \\
\text { 3. Expansion of a package of health and recreation } \\
\text { and medical services and diversification of the tourist } \\
\text { product. }\end{array}$ & $\begin{array}{l}\text { 1. Negative impact of instability of } \\
\text { social and economic conditions in the } \\
\text { country on the tourist industry in } \\
\text { general; } \\
\text { 2. Impairment of ecological conditions } \\
\text { and loss of recreational resources due to } \\
\text { the unsustainable use of natural } \\
\text { resources. }\end{array}$ \\
\hline
\end{tabular}

Aiming at improvement of health and recreation tourism, one should note the pressing issues that reflect the state of and affect this tourist industry. These issues can be split into several levels as shown in Table 2.

Table 2. "The issues that might affect the development of health and recreation tourism".

\begin{tabular}{|c|c|c|}
\hline Level & Issue description & Focus of impact \\
\hline \multirow{4}{*}{ International } & Population urbanization & Stimulation \\
\cline { 2 - 3 } & Population ageing & Stimulation \\
\cline { 2 - 3 } & Change in consumer preferences & $\begin{array}{c}\text { Stimulation or } \\
\text { suppression }\end{array}$ \\
\cline { 2 - 3 } & $\begin{array}{c}\text { Insufficient effective use of marketing tools in tourist } \\
\text { service sales }\end{array}$ & Suppression \\
\cline { 2 - 3 } Federal & Competition growth & Stimulation \\
\hline \multirow{3}{*}{} & $\begin{array}{c}\text { Absence of a unified institution to coordinate health } \\
\text { and recreation tourism activity }\end{array}$ & Suppression \\
\cline { 2 - 3 } & $\begin{array}{c}\text { State support of the health and recreation complex } \\
\text { through financing from non-budget funds }\end{array}$ & Stimulation \\
\hline
\end{tabular}




\begin{tabular}{|c|c|c|}
\hline & $\begin{array}{c}\text { Absence of the annual medical examination system } \\
\text { (besides compulsory preventive health examination) }\end{array}$ & Suppression \\
\cline { 2 - 3 } & Environmental deterioration & $\begin{array}{c}\text { Stimulation or } \\
\text { suppression }\end{array}$ \\
\cline { 2 - 3 } Insufficiently developed transport infrastructure & Suppression \\
\cline { 2 - 3 } & Change in consumer preferences & $\begin{array}{c}\text { Stimulation or } \\
\text { suppression }\end{array}$ \\
\cline { 2 - 3 } & $\begin{array}{c}\text { Inconsistency of "value" and "quality" categories of } \\
\text { the service }\end{array}$ & Suppression \\
\cline { 2 - 3 } & $\begin{array}{c}\text { Lack of understanding of importance of health and } \\
\text { recreation tourism by administrative authorities of } \\
\text { constituent entity of the Russian Federation }\end{array}$ & Suppression \\
\cline { 2 - 3 } & Absent or lower investment activity & Supren \\
\hline
\end{tabular}

One should also note that health and recreation tourism develops rapidly and has utmost social and economic significance as shown in:

- Higher municipal incomes and share of currency earnings;

- Creation of new jobs;

- Development of industries related to performance of health and recreation services (production, transport, communications, etc.);

- Development and improvement of the production infrastructure in the territory of tourist flows;

- Growth of the living standards of population, including cultural aspect development.

Positive effect of tourism on state economy occurs only when tourism develops in the country in its entirety, i.e. it does not turn the national economy to service economy. In other words, economic effectiveness of tourism suggests that tourism in the country should develop in parallel and in conjunction with other industries of the social and economic complex.

Intensive and stable growth of international tourist arrivals attests to the fact that ever since tourism has begun its development, it became affordable for people at large.

In the tourist industry, growth rates of scopes of services provided lead to the greater number of jobs faster compared to other industries. The time interval between growth of demand for tourist services and emergence of new jobs in the tourist business is minimal.

Consequently, the recreational tourist industry has positive impact on the national economy as it strives for comprehensive development of tourism which, in turn, improves servicing quality for tourists.

Significance of health and recreation tourism both domestically and abroad is quite great. This is connected with the fact that it is continuously developing as shown in:

- Better servicing quality for tourists, as demonstrated in better treatment quality;

- Cultural and esthetic rules and guidelines are observed;

- $\quad$ Emergence of the wide range of leisure activities.

Again, it should be noted that growth of competitiveness of national health and recreation tourism must be also driven by other market participants based on the following aspects:

1. Focus on the complex approach to marketing process management (pricing, promotion of health and recreation services, control over quality of services provided);

2. Differentiation of health and recreation services provided to satisfy the vacationists' needs (only treatment or only recreation, provision of services based on the discount system and special offers, etc.); 
3. Improvement of the training level of employees able to provide health and recreation services based on quality standards and service certification system;

4. Implementation of automation of the health and recreation tourist segment that would allow top-quality tourist services to be provided in real time;

5. Enhancement of material, technical and technological resources of a health and recreation provider that would allow administering top-quality medical and recreational assistance;

6. Introduction of additional tourist services to the health resort package that would allow improvement of package tour attractiveness;

7. Useing benchmarking tools through review and implementation of innovations, and analysis of competitor weaknesses;

8. Review of different medical documents to identify quality of services provided (e.g. review of patients' medical records);

9. Various quantitative (e.g. mass surveys) and qualitative marketing research (e.g. indepth interviews with patients);

10. Using the "mystery patient" methodology, which is similar to the "mystery shopping" methodology.

Combination of ever-changing social and political conditions and processes might favorably contribute to the increasing demand for health and recreation services in the domestic market.

Recently, amid the national population decline, higher mortality rate versus birth rate and higher overall sick rate among adults and children, it would stimulate development of the industry that might be possible, mainly, through creation of the health and recreation service quality control system. As already mentioned, creation of a mechanism like this would allow to assess the degree of patients' satisfaction and analyze how promptly the medical personnel could respond to patients' feedback regarding servicing and quality of services provided.

To resolve issues associated with provision of preventive care, treatment of the number of diseases and recreation of Russian population, the bigger emphasis should be on expansion and active development of the health resort network at various levels (federal, regional and municipal).

Medical tourism has drastically changed through the divergent role played by stakeholders over the years. Augmented competition has pulled various other stakeholders into the trade. Principally, policymakers, community and other private participants have played noteworthy roles in globalizing healthcare systems. Proficiency in delivering healthcare services and lesser perplexity in the healthcare network can enhance the capacity building process. Quality and standard assurance are prime parameters in benchmarking medical hubs to prosper.

The domestic sanatorium and health resort complex can drive the tourist flow thanks to diverse quality improvements such as development of the health resort infrastructure, informing tourists themselves and tourist business participants on the improved recreation conditions and new health procedures, etc.

One should also focus on improvement of transport accessibility, development of necessary natural therapeutic factors, continuous improvement of the servicing levels and infrastructure quality.

Summing up the above, one can conclude that effective implementation of competitive advantages of domestic health and recreation compounds both by the government and other participants in this market would allow creation of a competitive tourist product. Moreover, implementation of the above initiatives would allow the tourist attractiveness and competitiveness of the domestic health and recreation complex to be improved and, in 
doing so, retain our compatriots in Russian health resorts as well as engage and attract tourists from abroad.

\section{References}

1. Decree № 941-r (revised on 26.10.2016) of the Government of the Russian Federation dated 31.05.2014 "On approval of the strategy for tourism development in the Russian Federation by 2020 "

2. E. L. Andreyanova (et al.), Pressing issues of economics, management and tourism: collection of research articles (Irkutsk State Linguistic University, Irkutsk, 2015)

3. M. A. Zhukova, Business management (Finance and statistics, Moscow, 2014)

4. E. B. Tishuk, Issues of social hygiene of healthcare and history of medicine, 15 (2015)

5. A. M. Vetitnev, A. A. Torgasheva, Kurortniye Vedomosti, 1, 102, (2016)

6. L. V. Krivoruchko, Fundamental and applied issues in instrument engineering, information science, economics and law: Academic papers, IV International Research and Practice Conference, Part II, (2014) 